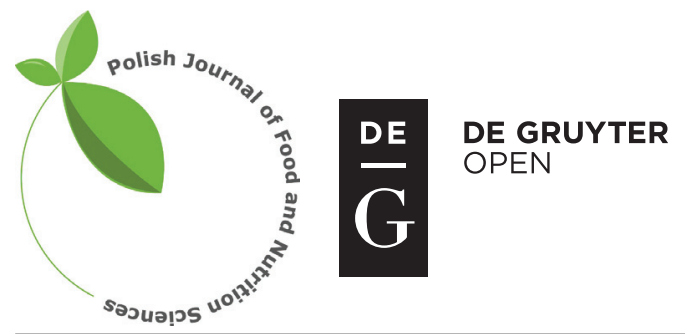

Pol. J. Food Nutr. Sci., 2017, Vol. 67, No. 1, pp. 19-24

DOI: $10.1515 /$ pjfns-2015-0046 http://journal.pan.olsztyn.pl

Original article

Section: Food Quality and Functionality

\title{
A Novel Spice: Pickled Pepper Powder and Some Quality Aspects
}

\author{
Harika Cankaya $^{1}$, Ibrahim Hayoglu ${ }^{1 *}$, Huseyin Turkoglu ${ }^{2}$ \\ ${ }^{1}$ Harran University Agricultural Faculty, Food Engineering Department, Sanliurfa, Turkey \\ ${ }^{2}$ Mugla University, Ula Ali Koçman Vocational High School, Mugla, Turkey
}

Key words: chili, paprika, pepper powder, phenolic, pickle

An alternative pepper powder with better sensory quality was produced from some pickled pepper species. The peppers pickled via traditional and quick methods were dried at $65 \pm 1{ }^{\circ} \mathrm{C}$, ground and physical, chemical and sensory characteristics of the samples were compared to those of commonly consumed pepper powders (control). Capsicum species grown in Turkey including Chili, Kapia, Jordan. Biberiye, Frenk and etc. were used. The results are expected to contribute to the development of new products, to provide more alternatives for consumers in the market and to satisfy consumer expectations. Along with typical pickled aroma, hotness and colour, pickled pepper powders may be a valuable food additive especially for ready-to-eat and fast foods.

\section{INTRODUCTION}

Hot pepper is commonly cultivated in many countries, and highly appreciated as condiment for its characteristic flavour, pungency, and colour as well as its content of antioxidant compounds. The content of capsaicin imparts pepper a wide range of tastes from sweet to very hot. It is consumed as fresh or processed in various forms including paste, pickled or dried. It is generally used as an ingredient in foods to impart them a bright red colour and a unique flavour.

Globally, 30,806,263 tonnes of fresh and 3,404,219 tonnes of dried chilies and peppers were produced in the year 2012. The largest share of this amount was produced in China, followed by Mexico and Turkey. With annual production of 2,042,360 tonnes of fresh and 16,500 tonnes of dried [F.A.O., 2015], Turkey has approximately a share of $8.94 \%$ of total world production.

Pepper is an important source of ascorbic acid, tocopherol, and other phytochemicals [Paksoy \& Uslu, 2006]. Ascorbic acid and phenolic compounds help prevent oxidative stress-mediated chronic diseases such as cancer, cardiovascular diseases, and hypertension, stroke, and neurodegenerative disorders, thus play a key role in the nutritional and commercial quality of pepper. It is reported that $100 \mathrm{~g}$ of fresh pepper provide the daily recommended amount of ascorbic acid (60 mg) [Deepa et al., 2006]. The antioxidant activity of red pepper was effected by drying conditions, and a modified drying in short time at low temperature was more effective than

\footnotetext{
* Corresponding Author: Tel : +90 4143183721; Fax : +90 4143183682; E-mail: hhayoglu@harran.edu.tr \& hayoglu@hotmail.com (Prof. Ibrahim Hayoglu)
}

conventional drying in reducing the destruction of the antioxidant activity, ascorbic acid and colour [Kim et al., 2006].

The main pigment of pepper, capsanthin, is regarded as a functional compound stimulating singlet oxygen-quenching ability [Hirayama et al., 1994] and preventing colon carcinogenesis [Narisawa et al., 2000].

Production process of flake or powdered pepper includes washing and slicing of the ripened red peppers into 2 or 4 parts, air drying at $65-70^{\circ} \mathrm{C}$ and grinding. In some cases, seed slot is generally removed during slicing stage. Drying process is completed approximately within 6 hours for sliced or within 12 hours for whole peppers where the product has 7-8\% moisture content [Cemeroğlu \& Acar, 1986]. Lower water activity in dried product helps reduce microbiological activity, so, dried pepper can be stored at ambient temperature for longer periods due to lower moisture and higher dry matter content. However, drying may cause physical and chemical changes including oxidation, shrinkage, the loss in colour and texture as well as the loss in nutritional and functional properties of the resultant product [Doymaz \& Pala, 2002; Attanasio et al., 2004; Vega-Gálvez et al., 2008].

Ascorbic acid (vitamin C) may degrade to some extent due to processing conditions such as temperature, salt, and/ or sugar concentrations, $\mathrm{pH}$, oxygen and enzymes. Particularly with peppers, the process of dehydration causes loss of ascorbic acid due to the application of high temperatures [da Silva et al., 2012]. Vitamin C content and the total phenolic content of dried peppers decreased as air-drying temperature increased from $50^{\circ} \mathrm{C}$ to $90^{\circ} \mathrm{C}$ [Vega-Gálvez et al., 2009].

Pickling is one of the old preservation methods. Traditional methods of food preservation, such as pickling, have reemerged as popular approaches for home and commer- 
cial food processing. Pepper is pickled alone or mixed with other vegetables including gherkin, cabbage, cucumber, green beans, garlic, green tomatoes, carrot etc., and consumed with meals to enhance their taste, and as an appetizer.

In many ready-to-eat meals and fast foods, pickled pepper is preferred as an ingredient, however, its high water content may have some drawbacks, for example, it may cause the partial rehydration of the product to get wetter and increase the risk of microbial activity. In addition, the use of fresh and pickled pepper is slightly limited because of their quality deterioration during storage and short shelf life [Park et al., 2011]. Dried red pepper is recognised as a high risk product with regard to the production of aflatoxin [Hayoglu et al., 2005]. The development of pickled pepper powder might help overcome these problems, and create an alternative form for the proper use of pepper.

There is a need to develop pepper powder with characteristics of pickled pepper. To our best knowledge very few studies on pickled powder or scaled pepper are available although studies were performed on related products. This study intended to develop a new spice, pepper powder, from traditionally or quick pickled red and green peppers, and to investigate their sensory, chemical and physical properties.

\section{MATERIALS AND METHODS}

\section{Sample preparation}

In this study, green and red peppers pickled with traditional and quick (with vinegar) methods were collected from local markets and dried at $65 \pm 1^{\circ} \mathrm{C}$ in laboratory and fine grinded. All the pickled peppers were cut into 2 or 4 parts depending on size (little ones as a whole), and dried at $65 \pm 1^{\circ} \mathrm{C}$ in air flow for $6-10 \mathrm{~h}$. Afterwards, they were grinded using laboratory-type grinder. The samples were stored in small glass jars, in dark and ambient conditions. In this study, Capsicum species that are grown in Turkey including Chili, Kapia, Jordan, Biberiye and Frenk were used. Physical, chemical and sensory characteristics of the pickled pepper powder samples were compared to these of the commonly consumed pepper powder (control).

The samples obtained from pickled peppers were coded as follows:

$\begin{array}{clc}1 & \text { Mini Red Hot Chili-Traditional Pickled } & \text { MRHC-TP } \\ 2 & \begin{array}{l}\text { Sweet Red Kapia -Traditional Pickled } \\ 3\end{array} & \begin{array}{l}\text { Conic Long Green-Red Hot } \\ \text { Jordan Pepper-Quick Pickled }\end{array} \\ 4 & \begin{array}{l}\text { Conic Long Red Hot Jordan } \\ \text { Pepper-Quick Pickled }\end{array} & \text { CLGRJ-QP } \\ 5 & \text { Red Hot Chili-Quick Pickled } & \text { CLRHJ-QP } \\ 6 & \text { Mini Slim Green Hot Pepper-Traditional Pickled } & \text { MSGH-TP } \\ 7 & \begin{array}{l}\text { Mini Conic Yellow/Green Hot Pepper } \\ \text { (Biberiye)-Quick Pickled }\end{array} & \text { MCYGH-QP } \\ 8 & \text { Mini Slim Green Hot Pepper-Quick Pickled } & \text { MSGH-QP } \\ 9 & \text { Mini Red Hot (Frenk) Pepper-Quick Pickled } & \text { MRH-QP } \\ 10 & \text { Slim Long Red Hot Pepper (Fresh)-Control } & \text { SLRH-C } \\ 11 & \text { Mini Slim Green Hot Pepper (Fresh)-Control } & \text { MSGH-C }\end{array}$

\section{Physical and chemical analysis}

The samples were analysed for moisture content $\left(60^{\circ} \mathrm{C}\right)$, water activity (using water activity meter; AquaLab Series 3TE, Pullman, WA, USA), ash, pH (Onion 4 Star pH, Thermo Scientific), and acidity (expressed as acetic acid \%) [AOAC, 2000]. The $\mathrm{pH}$ and acidity of the brine were also determined.

Total phenolic contents (TPC) were estimated as gallic acid equivalents using Folin-Ciocalteau's (FC) method [Singh et al., 2002] adapted to a micro-scale according to a procedure described by Medina-Remón et al. [2009].

Colour values were measured using Hunter Lab Colour Quest XE, and the results were recorded in $L^{*}$ (lightness), $+a^{*}$ (redness) and $+b^{*}$ (yellowness) according to CIE (Commission Internationale de I'Eclairage) colour coordinates, using the CIE C* illuminant which corresponds to the difference between average daylight and UV component. Saturation (Chroma, $C^{*}$ ) and colour tone (hue angle, $h^{\circ}$ ) was calculated from $a^{*}$ and $b^{*}$ colour coordinates using the following equations [Horvath \& Hodur, 2007]:

$$
C^{*}=\left[a^{* 2}+b^{* 2}\right]^{1 / 2} \quad \mathrm{~h}^{\circ}=\tan ^{-1}\left[b^{*} / a^{*}\right]
$$

All analyses were performed in triplicate.

\section{Sensory analysis}

Sensory evaluation was carried out as outlined by Moskowitz et al. [2003]. The pepper samples were evaluated for colour, odour, taste and aroma (pungency, acidic taste, intensity of flavour), after-taste impression and overall acceptability by 10 panellists, the members of the Education Board of the Department of Food Engineering, Harran University. For taste and aroma evaluation, $0.5 \mathrm{~g}$ of each powder pepper sample was mixed thoroughly with $40 \mathrm{~mL}$ of yoghurt, and served to the panellists as coded with three-digit numbers. The panellists recorded their ratings using a 10-point hedonic scale $(10=$ like very much; $1=$ dislike very much $)$.

\section{Statistical analyses}

The study was arranged as randomised complete blocks. Variance analysis was applied to the data. Duncan's multiple range tests were applied to the significant means using STATISTICA (ver. 5.0, 1995) package software.

\section{RESULTS AND DISCUSSION}

Table 1 shows the chemical composition and some properties of pickled pepper powders. The drying yields (\%, dry product obtained from wet-product) of the samples ranged between $7.93 \%$ and $23.35 \%$, average being $12.58 \%$. Fleshy pepper samples (Kapia and Jordan peppers) had generally significantly $(\mathrm{p}<0.05)$ lower drying yields (Table 1$)$.

It is expected that the diffusion of water-soluble solids from peppers into brine and the salt from brine into peppers occur in different extents for each pepper. This may be one of the reasons for the different drying yields.

The moisture contents of the samples ranged from 5.58 to 14.57\%, average being 8.38\%. Turkish Codex Alimentarius limited moisture content of red pepper powder to $11 \%$. Moisture content in dried products is of great importance for sat- 
TABLE 1. Chemical composition and some properties of pickled pepper powders.

\begin{tabular}{|c|c|c|c|c|c|c|c|c|c|}
\hline \multicolumn{2}{|c|}{ Samples } & $\begin{array}{c}\text { Drying } \\
\text { yield }(\%)\end{array}$ & $\begin{array}{c}\text { Moisture } \\
(\%)\end{array}$ & $\begin{array}{c}\text { Water } \\
\text { activity }\left(\mathrm{a}_{\mathrm{w}}\right)\end{array}$ & $\begin{array}{l}\text { Ash } \\
(\%)\end{array}$ & $\begin{array}{c}\text { Acidity } \\
(\%)\end{array}$ & $\mathrm{pH}$ & $\begin{array}{c}\text { Acidity } \\
\text { (\%) (brine) }\end{array}$ & $\begin{array}{c}\mathrm{pH} \\
\text { (brine) }\end{array}$ \\
\hline 1 & MRHC-TP & $13.18^{\mathrm{d}^{* *}}$ & $8.93^{\text {bcd }}$ & $0.324^{\mathrm{a}}$ & $21.30^{\mathrm{d}}$ & $3.42^{\mathrm{b}}$ & $3.834^{\mathrm{bc}}$ & $0.72^{\mathrm{c}}$ & $3.25^{\mathrm{bc}}$ \\
\hline 2 & K-TP & $7.93^{\mathrm{a}}$ & $7.01^{\text {bcde }}$ & $0.234^{\mathrm{a}}$ & $32.12^{\mathrm{b}}$ & $3.3^{\mathrm{bc}}$ & $3.466^{\mathrm{a}}$ & $0.59^{\mathrm{b}}$ & $3.01^{\mathrm{de}}$ \\
\hline 3 & CLGRJ-QP & $9.38^{\mathrm{abc}}$ & $9.17^{\mathrm{bc}}$ & $0.217^{\mathrm{a}}$ & $17.61^{\mathrm{e}}$ & $6.3^{\mathrm{a}}$ & $3.348^{\mathrm{a}}$ & $1.98^{\mathrm{f}}$ & $2.82^{\mathrm{ef}}$ \\
\hline 4 & CLRHJ-QP & $8.89^{\mathrm{ab}}$ & $9.59^{\mathrm{ab}}$ & $0.205^{\mathrm{a}}$ & $18.46^{\mathrm{d}}$ & $6.18^{\mathrm{a}}$ & $3.415^{\mathrm{a}}$ & $1.93^{\mathrm{f}}$ & $2.90^{\mathrm{def}}$ \\
\hline 5 & RHC-QP & $11.00^{\mathrm{abcd}}$ & $5.86^{\mathrm{e}}$ & $0.127^{\mathrm{a}}$ & $13.93^{\mathrm{f}}$ & $5.85^{\mathrm{a}}$ & $3.457^{\mathrm{a}}$ & $2.46^{\mathrm{g}}$ & $2.73^{\mathrm{f}}$ \\
\hline 6 & MSGH-TP & $14.02^{\mathrm{d}}$ & $7.26^{\mathrm{bcde}}$ & $0.132^{\mathrm{a}}$ & $42.69^{\mathrm{a}}$ & $1.56^{\mathrm{e}}$ & $4.412^{\mathrm{de}}$ & $0.12^{\mathrm{a}}$ & $5.21^{\mathrm{a}}$ \\
\hline 7 & MCYGH-QP & $12.31^{\mathrm{cd}}$ & $6.33^{\text {cde }}$ & $0.154^{\mathrm{a}}$ & $32.86^{\mathrm{b}}$ & $2.49^{\mathrm{cd}}$ & $3.618^{\mathrm{ab}}$ & $0.96^{\mathrm{d}}$ & $3.22^{\mathrm{bc}}$ \\
\hline 8 & MSGH-QP & $11.73^{\mathrm{bcd}}$ & $7.20^{\text {bcde }}$ & $0.136^{\mathrm{a}}$ & $29.52^{\mathrm{bc}}$ & $2.25^{\mathrm{de}}$ & $3.594^{\mathrm{ab}}$ & $1.14^{\mathrm{e}}$ & $3.07^{\mathrm{cd}}$ \\
\hline 9 & MRH-QP & $23.35^{\mathrm{e}}$ & $5.58^{\mathrm{e}}$ & $0.154^{\mathrm{a}}$ & $27.92^{c}$ & $3.15^{\mathrm{bc}}$ & $4.131^{\mathrm{cd}}$ & $2.40^{\mathrm{g}}$ & $3.31^{\mathrm{b}}$ \\
\hline 10 & SLRH-C & $13.96^{\mathrm{d}}$ & $14.57^{\mathrm{a}}$ & $0.300^{\mathrm{a}}$ & $6.28^{\mathrm{g}}$ & $3.27^{\mathrm{bc}}$ & $4.605^{\mathrm{e}}$ & $-{ }^{*}$ & $-{ }^{*}$ \\
\hline 11 & MSGH-C & $11.72^{\mathrm{bcd}}$ & $5.91^{\mathrm{de}}$ & $0.198^{\mathrm{a}}$ & $6.86^{\mathrm{g}}$ & $1.65^{\mathrm{e}}$ & $4.713^{\mathrm{e}}$ & $-{ }^{*}$ & $-{ }^{*}$ \\
\hline
\end{tabular}

*The sample was not pickled (control), therefore they do not have brine $\mathrm{pH}$ values. ${ }^{* *}$ The means in the same column followed by different letters are significantly different $(\mathrm{p}<0.05)$.

isfactory microbiological stability and for a reasonable shelf life. The pickled peppers were dried to $15 \%$ moisture content. The initial moisture content of pepper powder is very important because it is strongly correlated with the stability of ascorbic acid and pigments as well as microbial aspects.

The water activity values of pepper powder samples were not statistically different $(p>0.05)$ indicating that regardless fruit type and production method, the products are suitable for storage with long shelf life. The water activity decreased with decrease in moisture content of the samples (Table 1). The ash contents of the samples ranged between $6.28 \%$ and $42.69 \%$, average being $22.83 \%$. Different diffusion rates of salt into fruits may result in variations in ash contents of samples. The pepper powder samples obtained from traditional pickled peppers (e.g. K-TP and MSGH-TP) contained higher levels of ash, which may be explained by higher amount of salt that they contain in tissues. The samples processed with quick method had lower ash content, probably due to shorter pickling period. The unpickled dried samples (control) had the lowest ash levels, since they were not kept in brine.

The titratable acidity of the brines changed from 0.12 to $2.46 \%$, depending on sugar content of fruits. The $\mathrm{pH}$ values of brine samples were consistent with acidity, ranging between 2.73 and 5.21. The higher acidities of the products obtained from the samples pickled by quick method were the result of the direct vinegar addition during the pickling.

Regarding $\mathrm{pH}$ and acidity values, the products were found to be affected by production process. Especially products processed by quick method had significantly higher $(\mathrm{p}<0.05)$ acidity (Table 1). It can be concluded that processing method may affect acidity and therefore the taste of the products.

Quick pickled samples had generally higher acidity values, which was especially observed in fleshy (e.g. Jordan peppers) products. This may be explained by the higher acid retention by fleshy tissues.
The samples showed significantly different $(p<0.05)$ total phenolic contents (Table 2). The phenolic contents of the samples varied between 980.7 and 2376.3 average being $1577.18 \mathrm{mg} / \mathrm{kg}$ gallic acid equivalent (Table 2). The sample K-TP had a significantly lower phenolic content, as a result of fruit property. Niklis et al. [2002] reported that peppers are well-known sources of neutral phenolic compounds and acidic phenolic compounds. Levels of these components can vary with genotypic differences, pre-harvest climatic conditions, cultural practices, maturity, harvesting methods, and postharvest handling procedures. Ozgur et al. [2011] reported that the fresh red peppers had higher phenolic contents $(130.79 \pm 2.141 \mathrm{mg} \mathrm{GAE} \mathrm{g/dw)}$ when compared to the other samples.

The total phenolic compounds found in the present research were higher than these reported by Howard et al. [2000]. Previous studies [Park et al., 2011] reported a decrease in phenolic compounds contents of pepper during the drying process, however, the results of the present study revealed that pickled pepper powder is still a rich source of phenolics.

The differences in colour values were statistically $(\mathrm{p}<0.05)$ significant (Table 2), which aroused from the differences in colour of each fruit type. The instrumental colour analysis revealed that the green pepper samples generally showed higher $\mathrm{L}$ values than the red samples, which may be attributed to brighter characteristics of the green colour. The $a^{*}$ values were higher in red peppers than those of green peppers. However, $b^{*}$ values of all samples were close to each other. Vega-Gálvez et al. [2009] reported that there was no statistically significant difference between fresh and air-dried at $70^{\circ} \mathrm{C}$ and rehydrated peppers with respect to $\mathrm{L}, a^{*}$ and $b^{*}$ values.

Visual colour is one of the most important quality characteristics of red pepper which affects the consumers' preferences. Results of sensory analysis for colour showed that the most preferred pepper was the sample MRHC-TP (Figures 1 and 2), which was followed by green samples MSGH-TP 
TABLE 2. Some properties of dried green and red pickled pepper powders.

\begin{tabular}{|c|c|c|c|c|c|c|c|}
\hline \multirow{2}{*}{\multicolumn{2}{|c|}{ Samples }} & \multicolumn{5}{|c|}{ Color } & \multirow{2}{*}{$\begin{array}{c}\text { Total phenolic } \\
\text { compounds }(\mathrm{mg} / \mathrm{kg})\end{array}$} \\
\hline & & \multirow{2}{*}{$\frac{\mathrm{L}^{*}}{41.22^{\mathrm{a}^{*}}}$} & \multirow{2}{*}{$\frac{\mathrm{a}^{*}}{22.53^{\mathrm{ab}}}$} & \multirow{2}{*}{$\frac{b^{*}}{18.81^{\mathrm{a}}}$} & \multirow{2}{*}{$\frac{C^{*} \text { value }}{29.35^{\mathrm{ab}}}$} & \multirow{2}{*}{$\begin{array}{c}\mathrm{h}^{\circ} \text { value } \\
39.862^{\mathrm{a}}\end{array}$} & \\
\hline 1 & MRHC-TP & & & & & & $1821.3^{\mathrm{bc}}$ \\
\hline 2 & K-TP & $58.22^{\mathrm{c}}$ & $14.04^{\text {bcd }}$ & $31.62^{\mathrm{b}}$ & $34.60^{\mathrm{ab}}$ & $66.056^{\mathrm{bc}}$ & $980.7^{\mathrm{a}}$ \\
\hline 3 & CLGRJ-QP & $47.89^{b}$ & $11.55^{\text {cde }}$ & $23.69^{\mathrm{ab}}$ & $26.36^{\mathrm{ab}}$ & $64.008^{\mathrm{bc}}$ & $1257.0^{\mathrm{gb}}$ \\
\hline 4 & CLRHJ-QP & $48.34^{b}$ & $12.80^{\mathrm{bcd}}$ & $24.17^{\mathrm{ab}}$ & $27.35^{\mathrm{ab}}$ & $62.092^{\mathrm{abc}}$ & $1551.0^{\mathrm{e}}$ \\
\hline 5 & RHC-QP & $48.14^{b}$ & $11.49^{\mathrm{de}}$ & $23.61^{\mathrm{ab}}$ & $26.26^{\mathrm{ab}}$ & $64.052^{\mathrm{bc}}$ & $1682.0^{\mathrm{d}}$ \\
\hline 6 & MSGH-TP & $63.72^{\text {cde }}$ & $2.80^{\text {ef }}$ & $21.39^{\mathrm{ab}}$ & $21.57^{b}$ & $82.542^{c}$ & $1762.3^{\mathrm{cd}}$ \\
\hline 7 & MCYGH-QP & $67.79^{\mathrm{e}}$ & $5.00^{\mathrm{def}}$ & $25.23^{\mathrm{ab}}$ & $25.72^{\mathrm{ab}}$ & $78.791^{\mathrm{c}}$ & $1467.7^{\mathrm{f}}$ \\
\hline 8 & MSGH-QP & $64.73^{\mathrm{de}}$ & $0.001^{\mathrm{f}}$ & $24.30^{\mathrm{ab}}$ & $24.30^{\mathrm{b}}$ & $50.006^{\mathrm{ab}}$ & $1247.0^{\mathrm{g}}$ \\
\hline 9 & MRH-QP & $48.03^{b}$ & $27.56^{a}$ & $28.28^{\mathrm{ab}}$ & $39.49^{a}$ & $45.735^{\mathrm{ab}}$ & $1600.0^{\mathrm{e}}$ \\
\hline 10 & SLRH-C & $47.84^{b}$ & $21.83^{\mathrm{abc}}$ & $26.02^{\mathrm{ab}}$ & $33.96^{\mathrm{ab}}$ & $50.006^{\mathrm{ab}}$ & $2376.3^{\mathrm{a}}$ \\
\hline 11 & MSGH-C & $58.95^{\text {cde }}$ & $4.15^{\mathrm{def}}$ & $24.35^{\mathrm{ab}}$ & $24.70^{\mathrm{ab}}$ & $80.327^{c}$ & $1901.0^{\mathrm{b}}$ \\
\hline
\end{tabular}

* The means in the same column followed by different letters are significantly different $(\mathrm{p}<0.05)$.

and MSGH-C. Rather than red or green colour of peppers, brightness (brilliant appearance) of the dried samples was more appreciated by the panellists, thus all the samples received scores over the general average. The sample K-TP received the lowest score due to its pale appearance. These results showed that colour of all samples would be accepted by consumers. It can be concluded that, as long as they keep their attractive colour, dried red and green pepper powders are likely to be preferred.

The results of the sensory evaluations showed that there was no marked difference in colour between control and pickled pepper samples. This result confirmed that fermentation did not have any negative effect on colour of the product. The lowest colour score received by Kapia may be attributed to the characteristics of species.

With respect to odour, the most preferred samples were MRH-QP, MRHC-TP, and MSGH-C. There was no marked difference between fermentation and direct acidifying processes, which developed odour quality of the products and led to higher organoleptic odour scores.

Investigating the effects of various drying methods (the Refractance Window-drying (RWD) method, freeze drying, hot-air oven drying, and natural convective drying methods) on the colour characteristics of paprika, Topuz et al.

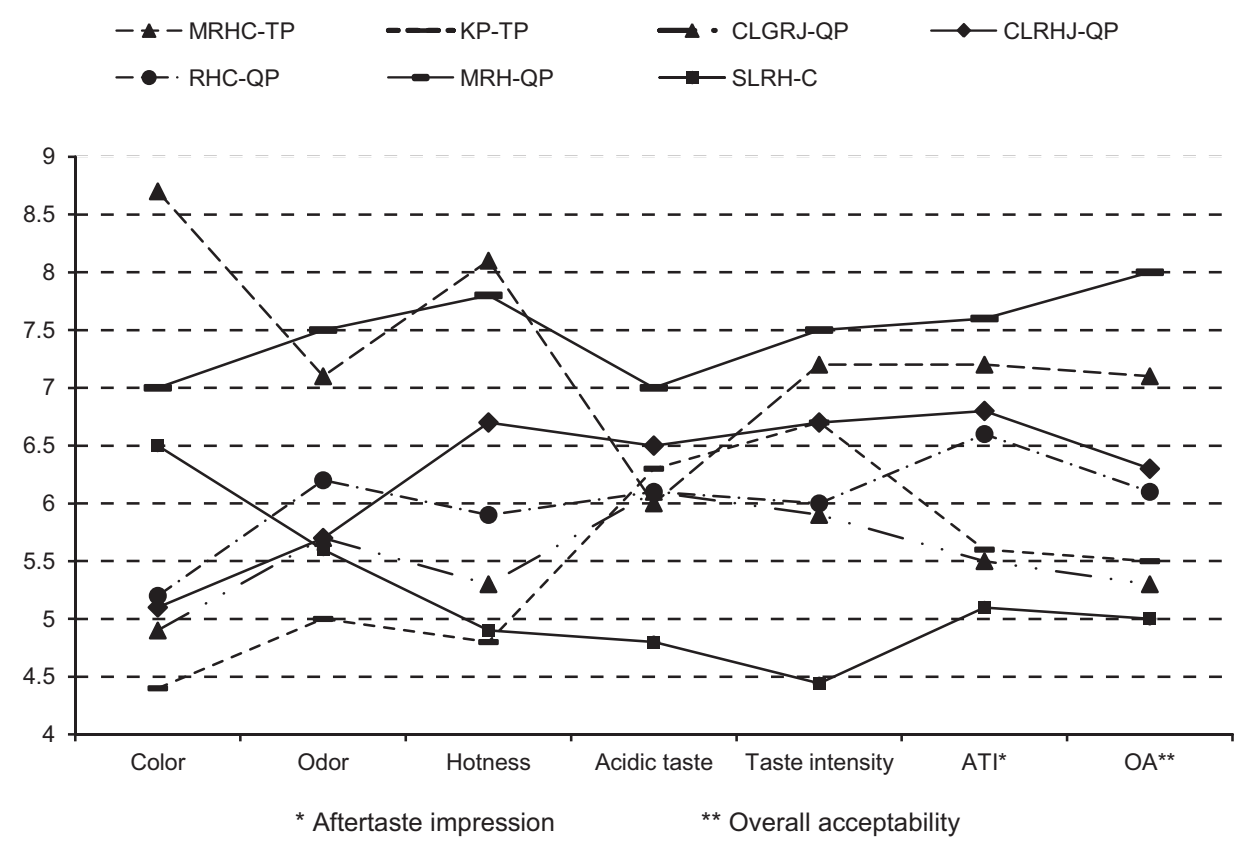

FIGURE 1. Sensory analysis of pickled red pepper powders. 


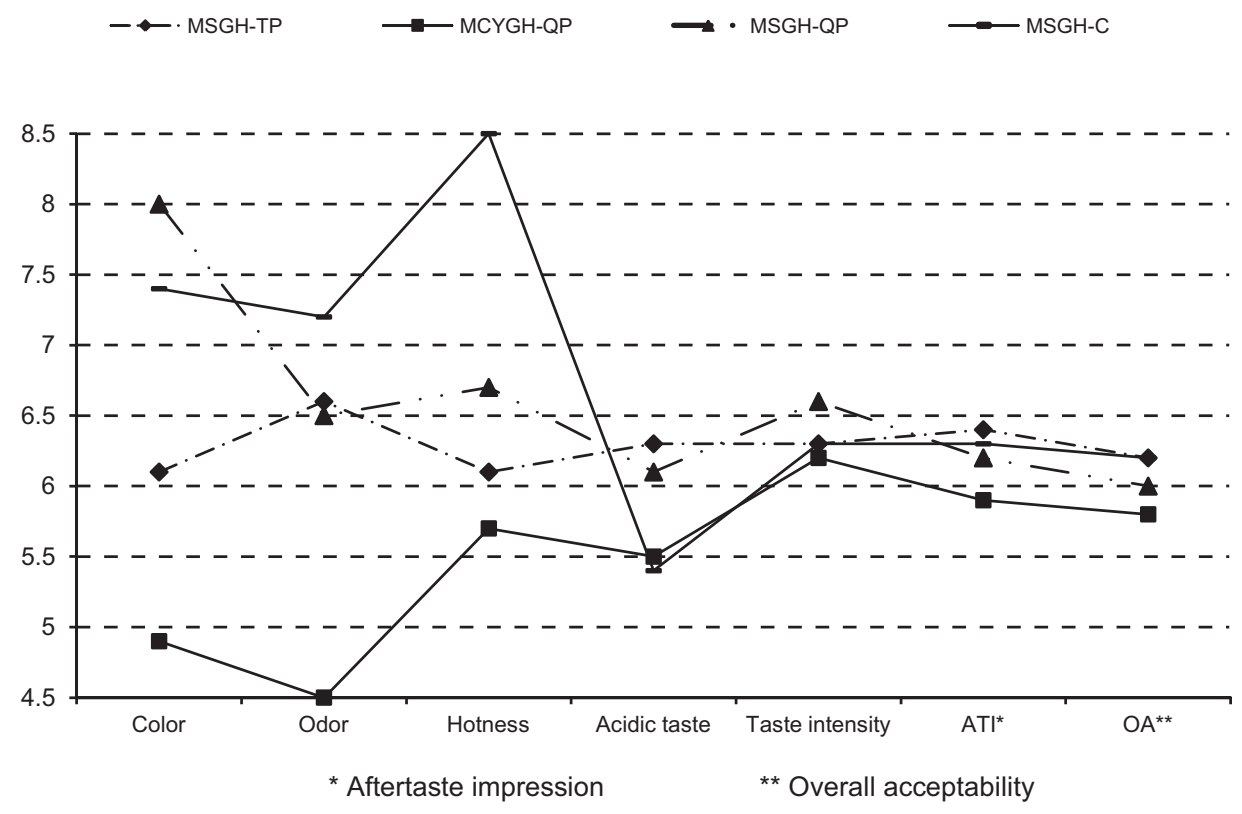

FIGURE 2. Sensory analysis of pickled green pepper powders.

[2009] found no significant difference in the browning index between freeze-dried and RWD-dried samples but they reported a gradual discoloration in all paprika samples during storage. They also stated that the surface colour degradation of the paprika was more related to browning reaction than to carotenoid degradation [Topuz et al., 2009].

In the present research, in order to evaluate hotness, a 0.5 -g sample was mixed thoroughly with $40 \mathrm{~mL}$ of yoghurt, and served to the panellists. The samples MRHC-TP, MCYGH-QP and MSGH-C received the highest hotness scores. Hotness of pepper is unique to each species. The fact that the sample MSGH-C (green pepper control sample) received hotness score similar to processed samples MRHC-TP and MCYGH-QP indicated that pickling methods had no distinct effect on sensorial hotness characteristics of the samples. Acid and $\mathrm{pH}$ values of the present samples were harmonious. Higher acidity and formation of aromatic taste rendered these products to be liked by panellists.

The acid taste in general had a slightly higher score in pickled samples when compared to control ones. Acid values of processed pepper powders were similar to each other and revealed that pickling methods did not affect the sourness of the samples. Both the quick and traditional pickling processes increased the acidity values of the samples, which was reflected by both acidity of products and $\mathrm{pH}$ values. High acidity and development of aromatic taste rendered the panellists to appreciate them. Pickled samples showed remarkably higher aroma intensity scores than the control, which indicates that as long as they maintain their unique pickled aroma, they have the potential for the preference by consumers. Processing methods did not affect the quality of the impression of aftertaste. Peppers processed via both traditional and quick methods were preferred to control for their aftertaste impression scores.

This study provides basic evidence that the pickling of hot pepper by both traditional and quick methods renders pepper powder more aromatic and help promoting properties.

\section{CONCLUSIONS}

As a conclusion, all the pickled peppers except fleshy and sweet Kapia were preferred with respect to quality criteria investigated. Despite drying and grinding processes, pickled pepper powders maintained intensive pickle aroma and they were preferred by panellists more than the control. Therefore, pickled hot pepper powders are considered as preferable additives especially for fast foods and salad dressings without causing excessive moisture in the product. Panels showed that hot samples were found to be better than sweet ones, and red peppers were better than green ones. The results of this research showed the possibility that pickled pepper could be used to produce pepper powder rich in aroma, keeping nutritional and functional components and satisfying consumer needs. In addition, drying and grinding process might enable the product easier to transport and store.

\section{ACKNOWLEDGEMENTS}

The study was financially supported by the Harran University, Food Engineering Department.

\section{CONFLICT OF INTERSET}

None declared.

\section{REFERENCES}

1. AOAC, Association of Official Analytical Chemists Official Methods of Analysis. 2000, Washington, DC, USA.

2. Attanasio G., Cianquanta L., di Matteo M.D., Effect of drying temperature on physico-chemical properties of dried and rehydrated chestnuts (Castanea sativa). Food Chem., 2004, 88, 583-590.

3. Cemeroğlu B., Acar J., Fruit and Vegetables Processing Technology. 1986, Food Tech. Assoc., No: 6, Ankara, Turkey. 
4. da Silva T.M., Argandoña E.J.S., Madrona G.S., Moraes, I.C.F., Haminiuk C.W.I., Branco I.G., Influence of osmotic dehydration on ascorbic acid loss in pickled dry peppers (Capsicum chinense). Braz. Arch. Biol. Technol., 2012, 55(5), 763-769.

5. Deepa N., Kaur C., Singh B., Kapoor H.C., Antioxidant activity in some red sweet pepper cultivars. J. Food Compos. Anal., 2006, 19, 572-578.

6. Doymaz I., Pala M., Hot-air drying characteristics of red pepper. J. Food Eng., 2002, 55, 331-335.

7. F.A.O. Food and Agriculture Organization of The United Nations. Faostat, 2015, [http://faostat.fao.org/].

8. Hayoglu İ., Didin M., Turkoglu H., Fenercioglu H., The effects of processing methods on some properties of hot red and redblackish ground peppers. Pakistan J. Biol. Sci., 2005, 8 (10), 1420-1423.

9. Hirayama O., Nakamura K., Hamada S., Kobayasi Y., Singlet oxygen quenching ability of naturally occurring carotenoids. Lipids, 1994, 29, 149-150.

10. Horvath Zs.H., Hodur C., Colour of paprika powders with different moisture content. Int. Agrophys., 2007, 21, 67-72.

11. Howard L.R., Talcott S.T., Brenes C.H., Villalon B., Changes in phytochemical and antioxidant activity of selected pepper cultivars (Capsicum species) as influenced by maturity. J. Agric. Food Chem., 2000, 48, 1713-1720.

12. Kim S., Lee K.W., Park J., Lee H.J., Hwang I.K., Effect of drying in antioxidant activity and changes of ascorbic acid and colour by different drying and storage in Korean red pepper (Capsicum annuum L.). Int. J. Food Sci. Technol., 2006, 41, 90-95.

13. Medina-Remón A., Barrionuevo-González A., Zamora-Ros R., Andres-Lacueva C., Estruch R., Martínez-González M.A., Diez-Espino J., Lamuela-Raventos R.M., Rapid Folin-Ciocalteau method using microtiter 96-well plate cartridges for solid phase extraction to assess urinary total phenolic compounds, as a biomarker of total polyphenols intake. Anal. Chim. Acta, 2009, 634, 54-60.

14. Moskowitz H.R., Muñoz A.M., Gacula M.C., Viewpoints and controversies in sensory science and consumer product testing. 2003, CT, USA: Food and Nutrition Press, Inc.
15. Narisawa T., Fukaura Y., Hasebe M., Nomura S., Oshima S., Inakuma T., Prevention of N-ethylnitrosourea-induced colon carcinogenesis in rats by oxygenated carotenoids capsanthin and capsanthin-rich paprika juice. Proc. Soc. Exp. Biol. Med., 2000, 224, 116-122.

16. Niklis N.D., Siomos A.S., Sfakiotakis E.M., Ascorbic acid, soluble solids and dry matter content in sweet pepper fruit: Change during ripening. J. Veg. Crop Prod., 2002, 8, 41-51.

17. Ozgur M., Ozcan T., Akpinar-Bayizit A., Yilmaz-Ersan L., Functional compounds and antioxidant properties of dried green and red peppers. Afr. J. Agric. Res., 2011, 6 (25), 5638-5644.

18. Paksoy M., Uslu Ö.S., The marketing and problems of red pepper in Turkey. VI. Symposium of Vegetable Cultivation, 19-22 September 2006, Kahramanmaraş-Turkey.

19. Park J., Kim S., Moon B.K., Changes in carotenoids, ascorbic acids, and quality characteristics by the pickling of paprika (Capsicum annuum L.) cultivated in Korea. J. Food Sci., 2011, 76 (7), 1075-1080.

20. Singh R.P., Murthy K.N.C., Jayaprakasha G.K., Studies on the antioxidant activity of pomegranate (Punica granatum) peel and seed extracts using in vitro models. J. Agric. Food Chem., 2002, 50, 81-86

21. Topuz A., Hao F., Kushad M., The effect of drying method and storage on color characteristics of paprika. Food Sci. Technol., 2009, 42, 1667-1673.

22. Vega-Gálvez A., Di Scala K., Rodríguez K., Lemus-Mondaca R., Miranda M., López J., Perez-Won M., Effect of air-drying temperature on physico-chemical properties, antioxidant capacity, colour and total phenolic content of red pepper (Capsicum annuum, L. var. Hungarian). Food Chem., 2009, 117, 647-653.

23. Vega-Gálvez A., Lemus-Mondaca R., Bilbao-Saïlnz C, Fito P., Andres A., Effect of air drying temperature on the quality of rehydrated dried red bell pepper (var. Lamuyo). J. Food Engin., 2008, 85, 42-50.

Submitted: 9 February 2015. Revised: 19 June and 24 June 2015. Accepted: 14 August 2015. Published on-line: 10 June 2016. 